\title{
HUBUNGAN PENGGUNAAN INSTAGRAM DENGAN MOTIVASI WIRAUSAHA PEBISNIS DARING (ONLINE) DALAM MENINGKATKAN PRODUKTIVITAS
}

\author{
Yasundari \\ Metro TV Biro Bandung
}

\begin{abstract}
ABSTRAK
Tujuan penelitian ini yaitu untuk mengetahui adakah hubungan antara penggunaan media sosial Instagram dengan motivasi wirausaha pebisnis daring pada komunitas SFS Family dalam meningkatkan produktivitas. Metode penelitian yang digunakan adalah survei eksplanatori dengan teknik analisis data inferensial. Teknik pengambilan data berupa kuesioner (angket), wawancara, observasi, dan studi pustaka. Kuesioner dibagikan kepada sampel dengan menggunakan teknik simple random sampling. Jumlah sampel dalam penelitian ini sebanyak 62 orang dengan teknik pengukuran menggunakan skala Likert. Hasil penelitian menunjukkan bahwa penggunaan media sosial Instagram memiliki hubungan yang signifikan cenderung kuat dengan motivasi wirausaha pebisnis daring pada komunitas SFS Family. Penggunaan media sosial Instagram memiliki hubungan yang signifikan cenderung sedang dengan peningkatan produktivitas. Motivasi wirausaha pebisnis daring pada komunitas SFS Family memiliki hubungan yang signifikan cenderung cukup sedang dengan peningkatan produktivitas. Saran bagi pebisnis daring anggota SFS Family, agar dapat lebih kompak dan memaksimalkan penggunaan media sosial Instagram dan lebih berhati-hati dengan cybercrime yang sangat rentan di transaksi dunia daring.
\end{abstract}

Kata-kata kunci: Media sosial, motivasi, bisnis, produktivitas, wirausaha

\section{THE CORRELATION OF THE USE OF INSTAGRAM WITH MOTIVATION FOR ONLINE BUSINESS SELLER TO INCREASE PRODUCTIVITY}

\begin{abstract}
This research was aimed on investigating is there any correlations between the use of social media Instagram with Business Motivation in Online Seller To Increase Productivity. The research employed quantitative survey explanatory method with inferensial data analysis technique. The data collected in the research was taken from two sources: the primary source was questionnaires delivered to 62 respondents and the secondary source was observation, literary study, and interview. The samples of this research were chosen by simple random sampling.The findings of the research shows that the use of social media Instagram has a significancy relationship near to strong relation to the business motivation of the online seller SFS Family Community. The use of social media Instagram has a significancy relationship near to middle relation to the productivity. The business motivation of the online seller SFS Family Community has a significancy relationship near to middle relation to the productivity. The recommendation of the research is that the members of SFS Family Community has to be more unite and maximizing the uses of social media Instagram and to be more careful of the cybercrime that really risky in online transactions.
\end{abstract}

Keywords: Social media, motivation, business, productivity, entrepreneurship

Korespondensi: Yasundari, S.I.Kom., M.I.Kom. Metro TV Biro Bandung Jalan Braga A5, Bandung, Jawa Barat 40111, Indonesia Email: yasundaririnandita@gmail.com 


\section{PENDAHULUAN}

Komunikasi dan manusia adalah dua hal yang tidak dapat dipisahkan dari kehidupan kita sebagai makhluk sosial. Sebagai manusia, kita melakukan komunikasi setiap harinya dengan berbagai cara dan juga berbagai media, salah satunya adalah dengan media internet yang sedang berkembang saat ini. Perkembangan dunia teknologi dan informasi semakin pesat dalam beberapa dekade terakhir, sehingga menjadikan internet sebagai alat komunikasi yang banyak diminati oleh masyarakat di seluruh dunia. Hal inilah yang melatarbelakangi perubahan komunikasi konvensional menjadi modern dan serba digital. Perkembangan inipun terasa menjadi semakin pesat setelah internet mulai dapat diakses melalui telepon seluler dan muncul istilah telepon cerdas (smartphone).

Selain untuk memenuhi kebutuhan informasi, saat ini media sosial banyak digunakan sebagai media penggerak perekonomian bagi para pengusaha. Adanya transaksi sarana jual beli daring di media sosial mulai marak untuk memenuhi kebutuhan para pengaksesnya. Para pemasar yang biasa memasarkan produknya melalui toko atau media konvensional kini mulai menggunakan internet sebagai media pemasaran. Mereka memasarkan produknya melalui toko daring (online shop). Ini merupakan toko yang menjual produk ataupun jasa melalui internet. Salah satu bentuk pemasaran interaktif ini telah menjadi tren berbelanja di kalangan masyarakat dewasa ini.

Membeli kebutuhan barang dan jasa melalui internet sudah menjadi suatu rutinitas konsumen saat ini (Kotler, 2007). Alasan utama masyarakat beralih pada toko daring adalah mereka dapat berbelanja tanpa terikat ruang dan waktu, artinya bisa dilakukan kapanpun dan di manapun, berbiaya rendah, cepat diketahui orang, dan bisa membuka banyak toko tanpa memikirkan biaya sewa (Marketing, 2012). Masyarakat juga dapat membandingkan harga dan kualitas produk dari satu toko dengan toko yang lain tanpa harus berjalan memasuki tokotoko tersebut. Melalui toko daring, pembeli tidak harus bertatap muka dengan penjual. Hanya dengan mengakses situs toko tersebut maka transaksi dapat berjalan.

Dalam pemasaran yang dilakukan toko daring, terdapat beberapa media daring dan juga media sosial yang sering digunakan, seperti Facebook, Twitter, Website, Flickr, Tumblr, dan Instagram. Penulis akan memfokuskan objek penelitian pada media sosial Instagram karena media sosial tersebut memiliki keunikan tersendiri dalam memfasilitasi pengguna (user) untuk berkomunikasi dibandingkan media sosial lainnya serta bagaimana penggunaan Instagram itu sendiri. Dalam hal ini para penggunanya yaitu para pebisnis daring yang menggunakan Instagram dalam memperjualbelikan produknya masing-masing.

Instagram adalah aplikasi berbagi foto yang memungkinkan pengguna mengambil foto, menerapkan filter digital, dan membagikannya ke berbagai layanan jejaring sosial, termasuk milik Instagram sendiri. Satu fitur yang unik di Instagram adalah memotong foto menjadi bentuk persegi, sehingga terlihat seperti hasil kamera Kodak Instamatic dan polaroid. Hal ini berbeda dengan rasio aspek 4: 3 yang umum digunakan oleh kamera pada peralatan bergerak.

Dalam media Instagram, fitur yang dimilikinyahanyaberupagambar danketerangan gambar sehingga memudahkan konsumen dalam berbelanja dan juga memilih barang. Beragam fitur yang dimiliki media daring memudahkan pemasar dalam berpromosi. Fitur-fitur tersebut memungkinkan pembeli dapat berinteraksi langsung dengan penjual. Pemasar dapat mengetahui keadaan pasar melalui informasi yang tersebar pada media daring. Pemasar juga dapat memantau keberadaan kompetitor yang berpeluang merebut pasar. Segala upaya yang dapat digunakan memasarkan produk akan digunakan pebisnis daring (Sulianta, 2012: 76).

Riset Nielsen (2015) juga menunjukkan Insta-gram menduduki peringkat yang lebih tinggi dibanding Twitter dalam 10 aplikasi terpopuler. Instagram dilihat sebanyak 32 juta orang perbulan dan terpaut Twitter sebanyak 30,8 juta orang. Dan menjadi aplikasi dengan pertumbuhan tercepat dari tahun sebelumnya sebanyak 66 persen.

Diperlukan adanya motivasi di dalam menjalankan suatu usaha agar para pebisnis daring semakin produktif untuk meningkatkan pendapatannya dan memajukan bisnis yang dijalankannya. Menurut Blocher, Chen, Lin (2000: 847) pengertian produktivitas adalah hubungan antara berapa keluaran (output) yang dihasilkan dan berapa masukan (input) yang 
dibutuhkan untuk memproduksi output tersebut. Menurut Husien Umar (1999: 9) produktivitas mengandung arti sebagai perbandingan antara hasil yang dicapai (output) dengan keseluruhan sumber daya yang digunakan (output).

Peningkatan produktivitas merupakan dambaan setiap perusahaan baik perorangan maupun perusahaan besar. Siapapun pasti tidak akan ada yang menginginkan bisnis atau usahanya hanya berjalan di tempat seiring waktu berputar. Oleh karena itu, semua pelaku usaha baik pebisnis daring maupun nondaring (offline) pun pasti selalu memutar otak dalam meningkatkan produktivitas usaha baik itu mengenai laba yang diraih ataupun juga kuantitas dan kualitas barang atau jasa yang tengah dikembangkan.

Produktivitas mengandung pengertian berkenaan dengan konsep ekonomis, filosofis, produktivitas berkenaan dengan usaha atau kegiatan manusia untuk menghasilkan barang atau jasa yang berguna untuk pemenuhan kebutuhan hidup manusia dan masyarakat pada umumnya. Sebagai konsep filosofis, produktivitas mengandung pandangan hidup dan sikap mental yang selalu berusaha untuk meningkatkan mutu kehidupan dimana keadaan hari ini harus lebih baik dari hari kemarin, dan mutu kehidupan hari esok harus lebih baik dari hari ini. Hal ini yang memberi dorongan untuk berusaha dan mengembangkan diri.

Saat ini pun segala macam barang dapat dijual melalui internet secara daring, bahkan aneka kuliner seperti makanan dan minuman. Para pebisnis daring pun berlomba-lomba mendapatkan pelanggan, sehingga mereka pun mengemas produknya semaksimal dan semenarik mungkin. Kalangan pebisnis daring di Instagram pun bersinergi untuk saling membantu dalam meningkatkan penjualan mereka. Media sosial Instagram seolah menjadi "toko" sekaligus grup untuk bersosialisasi bagi pebisnis daring untuk saling mengenal. Penulis meneliti salah satu komunitas pebisnis daring di Instagram yang bernama SFS Family dengan nama akun@ sfsfamily.

Salah satu fenomena penggunaan media sosial, khususnya Instagram di kalangan pebisnis daring inilah yang menarik perhatian penulis untuk mengkaji dan melakukan penelitian bahasan ini lebih lanjut. Dengan demikian penulis bermaksud untuk melakukan penelitian mengenai Hubungan Antara Penggunaan Media Sosial Instagram Pada Komunitas SFS Family Bandung Dengan Motivasi Wirausaha Dalam Meningkatkan Produktivitas.

Pada penelitian ini, peneliti ingin melihat hubungan yang terjadi antara penggunaan media sosial Instagram yang digunakan untuk berdagang dengan motivasi wirausaha dan juga produktivitas. Motivasi adalah kemauan untuk berbuat sesuatu, sedangkan motif adalah kebutuhan, keinginan, dorongan atau impuls. Motivasi seseorang tergantung kepada kekuatan motifnya. Motif dengan kekuatan yang sangat besarlah yang akan menentukan perilaku seseorang. Tujuan penelitian ini yaitu untuk mengetahui adakah hubungan antara penggunaan media sosial Instagram dengan motivasi wirausaha pebisnis daring pada komunitas SFS Family dalam meningkatkan produktivitas.

\section{METODE PENELITIAN}

Dalam penelitian ini, peneliti menggunakan metode survei eksplanatif (analitik). Jenis survei ini digunakan bila periset ingin mengetahui mengapa situasi atau kondisi tertentu terjadi atau apa yang memengaruhi terjadinya sesuatu. Periset tidak sekedar menggambarkan terjadinya fenomena tapi telah mencoba menjelaskan mengapa fenomena itu terjadi dan apa pengaruhnya. Dengan kata lain, periset ingin menjelaskan hubungan antara dua atau lebih variabel. Periset dituntut membuat hipotesis sebagai asumsi awal untuk menjelaskan hubungan antarvariabel yang diteliti. Analisis data menggunakan uji statistik inferensial.

Survei eksplanatif dapat dibagi dua sifat yaitu komparatif dan asosiatif. Penelitian ini menggunakan sifat survei eksplanatif asosiatif karena bermaksud untuk menjelaskan hubungan (korelasi) antarvariabel. Metode korelasional meneliti sejauhmana variasi pada satu faktor berkaitan dengan variasi pada faktor lain (Rakhmat, 2009: 27). Metode analisis ditujukan untuk menguji hipotesis-hipotesis dan mengadakan interpretasi yang lebih mendalam tentang hubungan-hubungan (Nazir, 2009: 89). Dalam penelitian ini, variabel bebas (X) adalah penggunaan media sosial Instagram yang berkorelasi dengan variabel terikat $(\mathrm{Y})$ 
yaitu motivasi wirausaha pebisnis online pada Komunitas SFS Family dan variabel anteseden (Z) adalah faktor peningkatan produktivitas.

Populasi dalam penelitian ini adalah pebisnis daring yang aktif dalam menggunakan Instagram dan merupakan anggota Komunitas SFS Family yang anggotanya berasal dari kota Bandung dari setiap kelasklasifikasipengikutnya yang dapat mewakili seluruh anggota komunitas. Ketertarikan penulis meneliti komunitas tersebut adalah cara mendapatkan anggota yang selektif dan juga memiliki forum diskusi sesuai dengan klasifikasi daerah dan jumlah pengikut. Klasifikasi forum berdasarkan jumlah pengikut mulai dari 1001-5000, 5001-10.000, 10.00120.250, 20.251-40.000, dan 40.001-100.000. Melalui media sosial Instagram, para pebisnis daring dapat meraup keuntungan puluhan juta rupiah seiring meningkatnya jumlah pengikut.

Penulis memilih populasi di setiap kelas jumlah pengikut tersebut dengan pertimbangan pebisnis daring memiliki jam terbang menggunakan Instagram sudah cukup tinggi dan juga sudah tergolong pebisnis yang terpercaya diukur dari validasi jumlah pengikut yang bukan pengikut palsu (fake followers).

Berdasarkan data yang didapat penulis dari Arruhti Purnamasari selaku penanggung jawab atau koordinator komunitas SFS Family, seluruh anggotanya dalam grup diskusi sesuai klasifikasi kelas pengikut ada sebanyak 742 orang. Arruhti menjelaskan bahwa setiap bulannya diadakan pendataan untuk anggota yang aktif bergabung di forum diskusi. Selain itu, pertemuan nonformal anggota setiap kota rutin dilakukan per bulan. Untuk acara tahunan, Komunitas SFS Family mengadakan pertemuan di Jakarta yang bisa diikuti oleh seluruh anggota yang tersebar se-Indonesia. Akan tetapi, tidak menutup kemungkinan acara tahunan dilakukan di kota besar lainnya.

Sampel adalah bagian yang diambil dari populasi dan dapat mewakili populasi. Dalam penelitian ini, sampel ditarik dengan menggunakan dasar teknik sampel acak sederhana (simple random sampling) dimana setiap unit populasi dipilih secara acak serta memiliki peluang yang sama untuk menjadi sampel penelitian (Rakhmat, 1995: 79).

Syarat teknik sampling ini adalah tersedianya kerangka sampling atau daftar sampling. Kerangka sampling dalam penelitian ini adalah daftar lengkap semua unsur populasi, yang dalam hal ini yaitu daftar nama pebisnis daring yang tergabung dalam Komunitas SFS Family yang berasal dari Bandung sebanyak 62 orang.

Pada tahap pertama, penulis melakukan penyebaran angket atau kuesioner. Angket atau kuesioner tersebut merupakan indikator dari identifikasi masalah yang menjadi tujuan penelitian. Angket atau kuesioner yang disebarkan kepada sampel berbentuk angket sederhana (data responden) dan tabulasi (data penggunaan media sosial Instagram). Hal ini dipergunakan sesuai kebutuhan penulis.

Dalam pelaksanaan pemilihan anggota sampel, peneliti menggunakan random sampling secara ordinal. Menurut Hamidi (2007: 135) sampel ordinal adalah penetapan angka kelipatan atau interval tertentu sampai diperoleh ukuran sampel yang telah ditetapkan. Menetapkan angka kelipatan dilakukan dengan membagi ukuran populasi dengan ukuran sampel. Dalam kaitan ini peneliti menetapkan angka kelipatan dengan perhitungan: 164 (besar populasi) dibagi 62 (besar sampel) = 2,64 dibulatkan menjadi 3 .

\section{HASIL DAN PEMBAHASAN}

Data responden yang perlu dibahas yaitu data yang dianggap penting dan berkaitan dengan data penelitian, dengan demikian data tersebut akan memberikan gambaran mengenai latar belakang responden seperti jenis kelamin, usia, latar belakang pendidikan terakhir, dan status pekerjaan. Berikut ini akan digambarkan mengenai data responden yang merupakan anggota Komunitas SFS Family di Kota Bandung. Data responden tersebut dikelompokkan berdasarkan jenis kelamin, usia, latar belakang pendidikan terakhir, dan bidang usaha yang dijalankan.

Berdasarkan angket yang telah disebarkan kepada responden penelitian yakni anggota Komunitas SFS Family di Kota Bandung, sebanyak 62 orang diperoleh data pada Tabel 1.

\section{Tabel 1 Jenis Kelamin}

\begin{tabular}{cccc}
\hline No & Kategori & F & $\%$ \\
\hline 1 & Laki-laki & 13 & 20.9 \\
2 & Perempuan & 49 & 79.1 \\
\hline & Jumlah & 62 & 100.0 \\
\hline
\end{tabular}

Sumber: Hasil Penelitian, 2015

Tabel 1 menggambarkan responden ber- 
dasarkan jenis kelamin. Dari tabel tersebut diperoleh data bahwa dari jumlah total 62 responden, sebanyak 13 orang anggota komunitas $(20.9 \%)$ berjenis kelamin lakilaki dan 49 orang $(79.1 \%)$ berjenis kelamin perempuan. Hal ini mengindikasikan bahwa sebagian dari responden yakni pebisnis daring yang menggunakan Instagram berjenis kelamin perempuan. Hasil perbandingan dari data yang diperolehmenunjukkanjumlah persentase cukup jauh dan hal ini menunjukkan bahwa pebisnis daring laki-laki pun ada yang menggunakan Instagram untuk usaha.

Tabel 2 Latar Belakang Pendidikan

\begin{tabular}{cccc}
\hline No & Kategori & F & $\%$ \\
\hline 1 & SMA & 11 & 17.7 \\
2 & Diploma & 18 & 29.2 \\
3 & S1 & 27 & 43.5 \\
4 & S2 & 6 & 9.6 \\
\hline & Jumlah & 62 & 100.0 \\
\hline
\end{tabular}

Sumber: Hasil Penelitian, 2015

Tabel 2 menggambarkan frekuensi responden berdasarkan latar belakang pendidikan pebisnis daring yang menjadi responden penelitian. Dari total 62 responden, diperoleh data bahwa sebanyak 11 orang pebisnis daring yang menggunakan Instagram (17.7\%) memiliki latar belakang pendidikan jenjang SMA. Sebanyak 18 orang pebisnis daring $(29,2 \%)$ memiliki latar belakang pendidikan jenjang diploma. Sebanyak 27 orang pebisnis daring $(43,5 \%)$ memiliki latar belakang pendidikan Strata 1 (S1) dan sebanyak 6 orang pebisnis daring $(9,6 \%)$ memiliki latar belakang pendidikan jenjang S2. Hal ini menunjukkan sebagian besar responden yakni pebisnis daring yang menggunakan Instagram memiliki latar belakang pendidikan jenjang S1. Kemampuan menyerap informasi dan kebutuhan informasi bisa terkait dengan tingkat pendidikan. Oleh karena itu, peneliti menilai bahwa tingkat pendidikan perlu untuk diketahui peneliti.

Tabel 3 menunjukkan perolehan data responden berdasarkan usia. Berdasarkan data yang diperoleh dari angket yang telah disebarkan kepada 62 responden, dapat diketahui bahwa sebanyak 9 responden $(14,5 \%)$ berusia antara 17-21 tahun, sebanyak 18 orang responden $(29,1 \%)$ berusia antara 22-26 tahun, sebanyak
29 orang pebisnis daring $(46,8 \%)$ berusia antara 27-36 tahun, dan sebanyak 6 orang pebisnis daring $(9,6 \%)$ berusia $>36$ tahun. Persentase usia responden menunjukkan usia antara 22-36 tahun pebisnis daring yang masih produktif dalam menggunakan Instagram dalam menjalankan bisnisnya. Usia antara 22-36 tahun yang melek informasi dan melek teknologi dalam mengembangkan bisnis daring.

\section{Tabel 3 Usia Responden}

\begin{tabular}{cccc}
\hline No & Kategori & F & $\%$ \\
\hline 1 & $17-21$ tahun & 9 & 14,5 \\
2 & $22-26$ tahun & 18 & 29,1 \\
3 & $27-36$ tahun & 29 & 46,8 \\
4 & $>36$ tahun & 6 & 9,6 \\
\hline & Jumlah & 62 & 100.0 \\
\hline
\end{tabular}

Sumber: Hasil Penelitian, 2015

Tabel 4 Jenis Bidang Usaha

\begin{tabular}{|c|c|c|c|}
\hline No & Kategori & $\mathrm{F}$ & $\%$ \\
\hline 1 & Kuliner & 16 & 25,8 \\
\hline 2 & Jasa & 9 & 14,5 \\
\hline 3 & Fashion/Konveksi & 21 & 33,8 \\
\hline 4 & Elektronik/Gadget/IT & 8 & 12,9 \\
\hline 5 & $\begin{array}{l}\text { Kerajinan/Handmade } \\
\text { Craft }\end{array}$ & 5 & 8,2 \\
\hline 6 & Lainnya & 3 & 4,8 \\
\hline & Jumlah & 62 & 100.0 \\
\hline
\end{tabular}

Sumber: Hasil Penelitian, 2015

Tabel 4 menunjukkan perolehan data responden berdasarkan jenis bidang usaha yang dijalankan oleh pebisnis daring yang menggunakan Instagram. Berdasarkan data yang diperoleh dari angket yang telah disebarkan kepada 62 responden, dapat diketahui bahwa sebanyak 16 responden $(25,8 \%)$ bergerak di bidang usaha kuliner. Sebanyak 9 responden $(14,5 \%)$ bergerak di bidang usaha jasa seperti desain dan periklanan. Sebanyak 21 pebisnis daring $(33,8 \%)$ bergerak di bidang usaha fashion/koveksi. Untuk bidang usaha elektronik/ gadget/IT sebanyak 8 responden $(12,9 \%)$ yang menekuninya. Sebanyak 5 responden $(8,2 \%)$ bergerak dalam bidang usaha kerajinan/industri kreatif/handmade craft, dan yang mengisi lainnya sebanyak 3 responden $(4,8 \%)$ bergerak di bidang usaha seperti kosmetik, obat-obatan, 
dan rokok elektrik.

Sebagian besar dari pebisnis daring memproduksi barang jualannya sendiri, tetapi ada pula yang menjadi pemasok (supplier) dan diperjualbelikan di media sosial Instagram.

Tabel 5 Lama Menekuni Bisnis

\begin{tabular}{cccc}
\hline No & Kategori & $\mathrm{F}$ & $\%$ \\
\hline 1 & $<1$ tahun & 4 & 6,4 \\
2 & 1 tahun & 9 & 14,5 \\
3 & 2 tahun & 14 & 22,6 \\
4 & 3 tahun & 22 & 35,5 \\
5 & $>3$ tahun & 13 & 21,0 \\
\hline & Jumlah & 62 & 100.0 \\
\hline
\end{tabular}

Sumber: Hasil Penelitian, 2015

Tabel 5 menunjukkan perolehan data responden berdasarkan lamanya menekuni bisnis. Berdasarkan data yang diperoleh dari angket yang telah disebarkan kepada 62 responden, dapat diketahui bahwa sebanyak 4 responden $(6,4 \%)$ sudah menekuni bisnis kurang dari satu tahun. Sebagian dari responden yaitu 9 orang $(14,5 \%)$ telah menekuni bisnis selama satu tahun. Sebanyak 14 responden $(22,6 \%)$ telah menjalankan bisnisnya selama dua tahun. Sebagian besar dari responden yaitu 22 orang $(35,5 \%)$ sudah menjalankan bisnisnya selama tiga tahun. Lalu sebanyak 13 responden $(21 \%)$ telah menjalankan bisnisnya lebih dari tiga tahun.

Berdasarkan dari data tersebut, hal ini menunjukkan bahwa sebagian besar responden telah menjalankan bisnisnya selama tiga tahun. Menjalankan bisnis bukanlah hal yang mudah dan yang paling sulit adalah mempertahankan dan mengembangkan suatu usaha. Semakin lama pebisnis menjalankan usaha, maka semakin banyak pula pengalaman naik dan turunnya usaha tersebut.

Tabel6Lama Menekuni Bisnis Menggunakan Media Sosial Instagram

\begin{tabular}{cccc}
\hline No & Kategori & F & $\%$ \\
\hline 1 & $<6$ bulan & 8 & 12,9 \\
2 & $7-9$ bulan & 4 & 6,4 \\
3 & $10-12$ bulan & 11 & 17,7 \\
4 & $13-24$ bulan & 13 & 21,0 \\
5 & $>24$ bulan & 26 & 42,0 \\
\hline & Jumlah & 62 & 100.0 \\
\hline
\end{tabular}

Sumber: Hasil Penelitian, 2015
Tabel 6 menunjukkan perolehan data responden berdasarkan lamanya pebisnis daring menekuni bisnisnya menggunakan media sosial Instagram. Berdasarkan data yang diperoleh dari angket yang telah disebarkan kepada 62 responden, dapat diketahui bahwa sebanyak 8 responden $(13,0 \%)$ menggunakan media sosial Instagram kurang dari 6 (enam) bulan untuk menjalankan bisnisnya. Sebanyak 4 responden $(6,4 \%)$ menggunakan media sosial Instagram untuk menjalankan bisnisnya selama 7-9 bulan. Sebanyak 11 (17,7\%) responden sudah menggunakan media sosial Instagram untuk menjalankan bisnisnya selama 10-12 bulan. Sebanyak 13 responden $(21,0 \%)$ sudah menggunakan media sosial Instagram selama 13-24 bulan untuk menjalankan bisnisnya, dan sebanyak 26 responden (41,9\%) selama lebih dari 24 bulan untuk menjalankan bisnis daringnya.

Berdasarkan data tersebut, dapat diketahui bahwa cukup banyak pebisnis daring yang sudah telah lama menggunakan media sosial Instagram untuk menjalankan bisnisnya. Hal ini pun menunjukkan media sosial Instagram bukan media sosial yang dapat dimanfaatkan secara temporer atau sementara.

\section{Tabel 7 Lamanya Bergabung Menjadi Anggota SFS Family}

\begin{tabular}{cccc}
\hline No & Kategori & F & $\%$ \\
\hline 1 & $1-3$ bulan & 7 & 11,3 \\
2 & $4-6$ bulan & 14 & 22,6 \\
3 & $7-9$ bulan & 5 & 8,1 \\
4 & $10-12$ bulan & 6 & 9,6 \\
5 & $>12$ bulan & 30 & 48,4 \\
\hline & Jumlah & 62 & 100.0 \\
\hline
\end{tabular}

Sumber: Hasil Penelitian, 2015

Tabel 7 menunjukkan perolehan data responden berdasarkan lama menjadi anggota SFS Family. Berdasarkan data yang diperoleh dari angket yang telah disebarkan kepada 62 responden, dapat diketahui bahwa sebanyak 7 responden $(11,3 \%)$ telah menjadi anggota $S F S$ Family selama kurun waktu 1-3 bulan lamanya. Sebanyak 14 responden $(22,4 \%)$ telah menjadi anggota SFS Family selama 4-6 bulan lamanya. Sebagian kecil responden yaitu 5 orang $(8,1 \%)$ telah menjadi anggota SFS Family selama 7-9 bulan. Sebanyak 6 responden $(9,6 \%)$ telah 
menjadi anggota SFS Family selama 10-12 bulan lamanya. Sedangkan sebagian besar dari responden yaitu sebanyak 30 orang $(48,4 \%)$ telah menjadi anggota SFS Family selama lebih dari 12 bulan atau lebih dari 1 tahun lamanya.

Tabel 8 Jenis Akun Instagram yang Digunakan

\begin{tabular}{|c|c|c|c|}
\hline No & Kategori & $\mathrm{F}$ & $\%$ \\
\hline 1 & \multirow{3}{*}{$\begin{array}{c}\text { Akun Pribadi } \\
\text { Akun pribadi yang sekaligus } \\
\text { digunakan untuk bisnis } \\
\text { Akun Khusus Bisnis }\end{array}$} & 4 & 6,5 \\
\hline 2 & & 13 & 20,9 \\
\hline 3 & & 45 & 72,6 \\
\hline & Jumlah & 62 & 100.0 \\
\hline
\end{tabular}

Sumber: Hasil Penelitian, 2015

Tabel 8 menunjukkan perolehan data responden berdasarkan jenis akun Instagram yang digunakan untuk bisnis. Berdasarkan data yang diperoleh dari angket yang telah disebarkan kepada 62 responden, dapat diketahui bahwa sebagian kecil dari responden yaitu sebanyak 4 orang $(6,5 \%)$ responden menggunakan akun Instagram pribadinya untuk menjalankan bisnis. Maksudnya adalah akun tersebut pada awalnya adalah akun personal tetapi setelah menjalankan bisnis, maka diisi konten yang berhubungan dengan bisnis yang dijalankannya. Sebanyak 13 responden $(20,9 \%)$ menggunakan akun pribadi yang sekaligus digunakan untuk bisnis.

Hal ini menunjukkan bahwa pengguna Instagram ini yakni responden dari anggota
SFS Family menggunakan akun pribadi yang sekaligus digunakan untuk bisnis, sehingga kontennya tercampur antara bisnis yang di jalani dengan foto pribadi atau yang tidak berkaitan dengan bisnisnya. Lalu sebagian besar responden yaitu sebanyak 45 responden (72,6\%) menggunakan akun Instagram yang khusus dibuat untuk kepentingan bisnis. Hal ini menunjukkan bahwa pebisnis daring lebih memilih untuk memisahkan antara akun pribadi dan akun khusus bisnis. Dengan demikian, pilihan tersebut dirasa lebih efektif untuk melakukan penjualan (selling) dan menunjukkan profesionalitas dari pebisnis daring. Selain itu, manfaat akun khusus bisnis tersebut membuat pengguna lebih fokus dalam menjalankan bisnisnya secara daring. Konsumen juga mendapat kemudahan dalam memilih kebutuhan yang sedang dicari melalui akun penjual yang khusus untuk berjualan.

Tabel 9 merupakan hasil analisis korelasi mengenai hubungan antara penggunaan media sosial Instagram (X) dengan motivasi wirausaha pebisnis daring pada komunitas SFS Family (Y).

Dari tabel tersebut diatas dapat diketahui bahwa besarnya hubungan antara penggunaan media sosial Instagram (X) dengan motivasi wirausaha pebisnis daring pada komunitas SFS Family(Y) adalah 0,695. Hubungan ini termasuk kategori kuat. Hasil pengujian dengan statistik $\mathrm{t}$ didapat nilai $\mathrm{t}_{\text {hitung }}(7,494)>\mathrm{t}_{\text {tabel }}(2,000)$.

Tabel 9 Hubungan Antara Penggunaan Media Sosial Instagram (X) dengan Motivasi Wirausaha Pebisnis Daring (Y)

\begin{tabular}{ccccccc}
\hline Variabel & $\mathrm{R}_{\mathrm{s}}$ & $\mathrm{t}$ hitung & $\mathrm{t}$ tabel & Keputusan & Keterangan & $\begin{array}{c}\text { Koefisien } \\
\text { Determinasi }\end{array}$ \\
\hline $\mathrm{X}$ dan $\mathrm{Y}$ & 0,695 & 7,494 & 2,000 & Ho Ditolak & $\begin{array}{c}\text { Terdapat } \\
\text { hubungan yang } \\
\text { signifikan }\end{array}$ & $48,3 \%$ \\
\hline
\end{tabular}

Sumber: Data yang sudah diolah peneliti, 2016

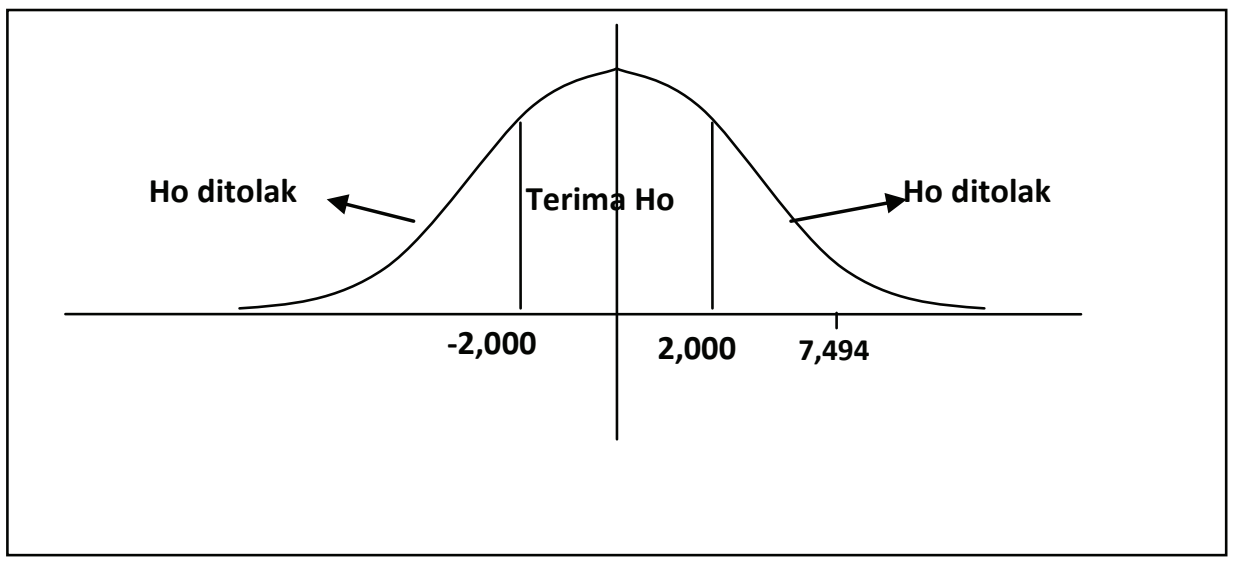

Gambar 1 Kurva Uji T Variabel X dan Y 
Hal tersebut mengindikasikan penolakan Ho yang menunjukan bahwa terdapat hubungan antara penggunaan media sosial Instagram (X) dengan motivasi wirausaha pebisnis daring pada komunitas SFS Family (Y).

Dari sini menjelaskan bahwa semakin tinggi penggunaan media sosial Instagram (X), maka akan semakin tinggi pula motivasi wirausaha pebisnis daring pada komunitas SFS Family (Y). Koefisien determinasi dari hasil perhitungan didapat sebesar 48,3\%. Hal ini memberikan pengertian motivasi wirausaha pebisnis daring pada komunitas SFS Family (Y) dipengaruhi oleh penggunaan media sosial Instagram $(\mathrm{X})$ sebesar 48,3\%, sedangkan sisanya $51,7 \%$ merupakan kontribusi variabel lain selain penggunaan media sosial Instagram (X). Oleh karena itu, dapat dilihat bahwa kebutuhan akan informasi merupakan dorongan bagi individu pebisnis daring untuk menggunakan media massa.

Dengan motif dorongan, kebutuhan dalam mencari informasi, dan tujuan untuk mencapai target bisnis melalui media sosial Instagram yang semakin besar, maka penggunaan media juga akan semakin tinggi dilakukan. Hal ini sesuai dengan teori kebutuhan dan motivasi dari Abraham Maslow.

Dari tabel 10 dapat diketahui bahwa besarnya hubungan antara penggunaan media sosial Instagram (X) dengan peningkatan produktivitas (Z) adalah 0,467. Hubungan ini termasuk dalam kategori sedang.

Hasil pengujian dengan statistik $t$ didapat nilai $\mathrm{t}_{\text {hitung }}(4,092)>\mathrm{t}_{\text {tabel }}(2,000)$. Hal tersebut mengindikasikan penolakan Ho yang menunjukan bahwa terdapat hubungan antara penggunaan media sosial Instagram (X) dengan peningkatan produktivitas (Z). Oleh karena itu, dapat ditarik kesimpulan bahwa semakin tinggi penggunaan media sosial Instagram (X), maka akan semakin tinggi pula peningkatan produktivitas (Z). Koefisien determinasi dari hasil perhitungan didapat sebesar 21,8\%. Hal ini memberikan pengertian peningkatan produktivitas $(Z)$ dipengaruhi oleh penggunaan media sosial Instagram (X) sebesar 21,8\%, sedangkan sisanya 78,2\% merupakan kontribusi variabel lain selain penggunaan media sosial Instagram (X).

Penelitian ini dimaksudkan untuk mencari jawaban terhadap suatu permasalahan yaitu apakah terdapat hubungan antara penggunaan media sosial Instagram dengan motivasi wirausaha pebisnis daring pada komunitas SFS Family dalam meningkatkan produktivitas usaha?

Analisis pertama, berdasarkan hasil penelitian dapat diketahui bahwa terdapat hubungan antara intensitas, isi pesan, dan prioritas peng-gunaan media sosial Instagram dengan motivasi wirausaha pebisnis daring. Sesuai dengan fungsi teori Uses and Gratifications bahwa alasan individu menggunakan media yaitu terbagi menjadi tiga yakni fungsi mengawasi,

Tabel 10 Hubungan Antara Penggunaan Media Sosial Instagram(X) dengan Peningkatan Produktivitas (Z)

\begin{tabular}{ccccccc}
\hline Variabel & $\mathrm{R}_{\mathrm{s}}$ & $\mathrm{t}$ hitung & $\mathrm{t}$ tabel & Keputusan & Keterangan & $\begin{array}{c}\text { Koefisien } \\
\text { Determinasi }\end{array}$ \\
\hline $\mathrm{X}$ dan Z & 0,467 & 4,092 & 2,000 & $\mathrm{H}_{0}$ Ditolak & $\begin{array}{c}\text { Terdapat hubungan yang } \\
\text { signifikan }\end{array}$ & $21,8 \%$ \\
\hline
\end{tabular}

Sumber: Data yang sudah diolah peneliti, 2016

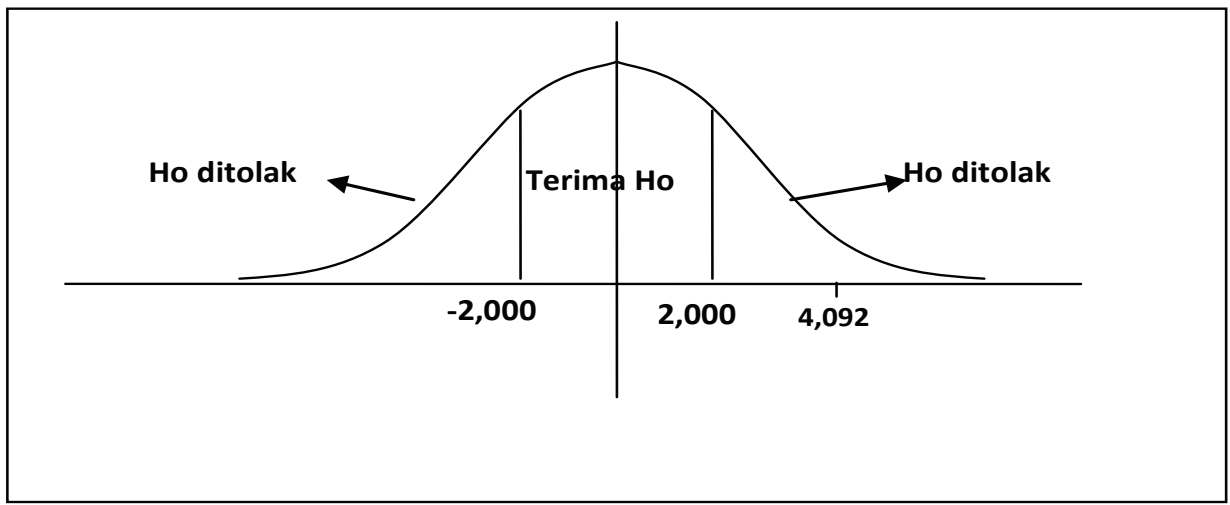

Gambar 2 Kurva Uji T Variabel X dan Z 
fungsi sosial, dan fungsi diversi.

Pada penelitian ini, pebisnis daring pada komunitas SFS Family sudah secara aktif memilih medianya untuk memenuhi kebutuhan informasinya yaitu media sosial Instagram. Asumsi dari teori Uses and Gratifications menurut Katz dan Blumer sendiri yaitu khalayak aktif dan penggunaan media berorientasi pada tujuan. Orientasi tujuan disini yaitu proses dalam menjalankan usaha para pebisnis daring untuk mencapai target dalam melakukan pemasaran dan penjualan yang lebih efektif daripada transaksi secara offline. Hal-hal seperti dimensi dari motivasi yaitu kebutuhan dalam menggunakan media sosial, lalu memahami maksud dan fungsi dari penggunaan media sosial tersebut, juga kebutuhan akan informasi melalui media sosial, dan mengetahui perkembangan terakhir mempunyai hubungan yang kuat dengan intensitas penggunaan media sosial Instagram.

Dalam menjalankan bisnisnya secara daring, pebisnis daring pada komunitas SFS Family suka berinteraksi dalam forum obrolan baik secara daring ataupun ketika bertatap muka. Mereka saling bertukar dan berbagi pengalaman sebagai pelaku usaha dan juga saling bertukar informasi. Hal ini menunjukkan para pebisnis daring membutuhkan interaksi sosial. Sesuai dengan teori kebutuhan dan motivasi Maslow dikenal sebagai teori Hierarchi of Needs yang dikutip Robbins (2003: 214) menyatakan bahwa dalam diri manusia masing-masing membutuhkan salah satunya faktor sosial yang mencakup rasa kasih sayang, rasa memiliki, diterima baik dalam perkumpulan komunitas, dan lain-lain. Selain itu, aktivitas anggota komunitas SFS Family dalam forum juga bisa dikaitkan dengan alasan individu dalam menggunakan media dengan fungsi sosial dimana penggunaan media bisa menjadi aktivitas sosial yang menyatukan orang-orang. Media juga dapat membantu kebersamaan dengan menciptakan kesamaan (Menurut Vivian, 2008).

Transaksi daring juga tentunya sangat rawan dengan cybercrime. Dalam media sosial Instagram sudah sangat familiar dengan istilah hack atau membajak akun. Hal ini yang harus diperhatikan oleh para pebisnis daring agar tidak dapat dibajak akunnya dan juga menghindari penipuan dari calon konsumen. Kebutuhan akan keamanan atau security needs juga masih sangat diperlukan oleh pebisnis daring. Hal ini pun sesuai dengan teori kebutuhan dan motivasi dari Maslow. Pebisnis daring memerlukan informasi yang cepat dan tanggap akan perkembangan yang sangat pesan di dunia jaringan online.

Sebagai pebisnis, ada hal yang dirasakan oleh masing-masing individu yaitu salah satunya dorongan untuk menjadi seseorang sesuai dengan ambisinya. Sebagai pebisnis pasti ada keinginan untuk maju dan melebihi rekan-rekan di sekitarnya. Hal ini sesuai dengan salah satu jenjang kebutuhan dan motivasi yang diungkapkan oleh Maslow.

Analisis kedua, terdapat hubungan yang signifikan antara penggunaan media sosial Instagram berdasarkan intensitas, isi pesan, dan prioritas penggunaannya dengan peningkatan produktivitas dalam hal ini terkait dengan usaha yang dijalankan pebisnis daring komunitas SFS Family. Hal ini disebabkan oleh beberapa faktor yang dibutuhkan oleh responden, yaitu strategi, efektivitas, dan efisiensi dalam menjalankan usaha oleh para pebisnis daring komunitas SFS Family dengan hasil yang cenderung sedang yaitu sebesar $21,8 \%$.

Analisis ketiga, terdapat hubungan yang signifikan antara motivasi wirausaha pebisnis daring komunitas SFS Family berdasarkan dorongan, kebutuhan, dan tujuan dengan peningkatan produktivitas. Hal ini disebabkan oleh beberapa faktor yang dibutuhkan oleh responden yaitu strategi, efektivitas, dan efisiensi dalam menjalankan usaha oleh para pebisnis daring komunitas SFS Family dengan hasil yang cenderung cukup sedang yaitu sebesar 18\%.

Hasil penelitian menunjukkan bahwa strategi sudah cukup dipertimbangkan oleh pebisnis daring untuk meningkatkan penjualan. Dalam menjalankan bisnis, strategi memang penting dilaksanakan seperti perencanaan yang matang, lalu bentuk pemasaran yang dilakukan pebisnis daring dalam hal ini anggota komunitas SFS Family. Berdasarkan temuan di lapangan, bentuk pemasaran yang dilakukan pebisnis daring banyak dari anggota komunitas SFS Family hanya memasarkan produknya melalui media sosial Instagram. Sesuai dengan pengalaman, mereka merasa penjualan di media sosial cepat tersebar dan lebih efektif. Untuk efisiensi tenaga, biaya, dan waktu produktivitas melalui media sosial Instagram juga sangat 
Tabel 11 Hubungan Antara Motivasi Wirausaha Pebisnis Daring Komunitas SFS Family (Y) dengan Peningkatan Produktivitas (Z)

\begin{tabular}{|c|c|c|c|c|c|c|}
\hline $\begin{array}{c}\text { Hubungan } \\
\text { Variabel }\end{array}$ & $\mathrm{R}_{\mathrm{s}}$ & $\mathrm{t}$ hitung & $\mathrm{t}$ tabel & Keputusan & Keterangan & $\begin{array}{c}\text { Koefisien } \\
\text { Determinasi }\end{array}$ \\
\hline $\mathrm{Y}$ dan Z & 0,424 & 3,624 & 2,000 & Ho Ditolak & $\begin{array}{c}\text { Terdapat hubungan yang } \\
\text { signifikan }\end{array}$ & $18,0 \%$ \\
\hline
\end{tabular}

Sumber : Data yang sudah diolah peneliti, 2016

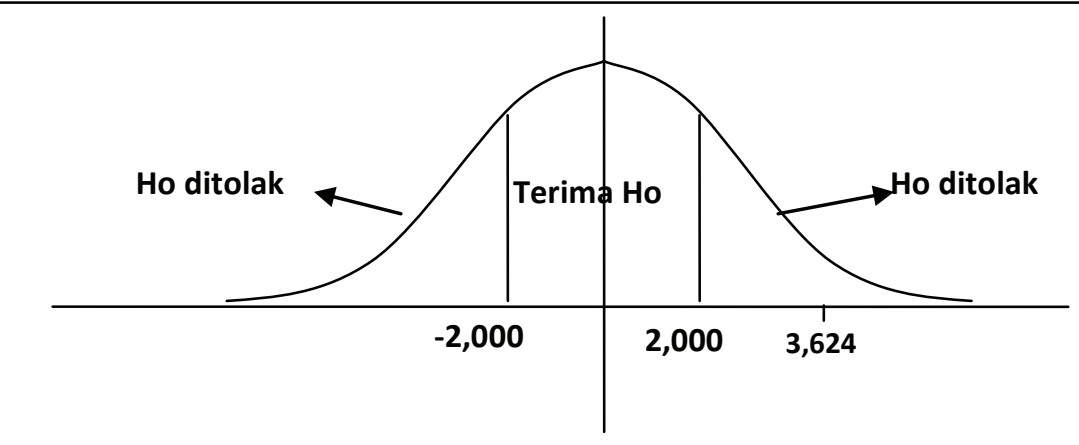

\section{Gambar 3 Kurva Uji T Variabel Y dan Z}

menunjang pebisnis daring seperti yang telah dijelaskan sebelumnya.

Dari tabel 11 dapat diketahui bahwa besarnya hubungan antara peningkatan produktivitas $(Z)$ dengan motivasi wirausaha pebisnis daring pada komunitas SFS Family (Y) adalah 0,424. Hubungan ini termasuk dalam kategori cukup sedang.

Hasil pengujian dengan statistik $t$ didapat nilai $\mathrm{t}_{\text {hitung }}(7,494)>\mathrm{t}_{\text {tabel }}(2,000)$. Hal tersebut mengindikasikan penolakan Ho yang menunjukan bahwa terdapat hubungan antara peningkatan produktivitas $(\mathrm{Z})$ dengan motivasi wirausaha pebisnis daring pada komunitas SFS Family (Y). Oleh karena itu, dapat ditarik kesimpulan bahwa semakin tinggi peningkatan produktivitas $(\mathrm{Z})$, maka akan semakin tinggi pula motivasi wirausaha pebisnis daring pada komunitas SFS Family (Y).

Koefisien determinasi dari hasil perhitungan didapat sebesar 18,0\%. Hal ini memberikan pengertian motivasi wirausaha pebisnis daring pada komunitas SFS Family (Y) dipengaruhi oleh peningkatan produktivitas (Z) sebesar 18,0\%, sedangkan sisanya 92,0\% merupakan kontribusi variabel lain selain peningkatan produktivitas (Z).

\section{SIMPULAN}

Berdasarkan hasil penelitian dan analisis pada bab sebelumnya, maka dari itu berdasarkan identifikasi dan tujuan dari penelitian ini yaitu ingin mengetahui bagaimana "Hubungan Antara Penggunaan Media Sosial Instagram Dengan Motivasi Wirausaha Pebisnis Daring (Online) Dalam Meningkatkan Produktivitas", maka peneliti dapat menarik beberapa simpulan sebagai berikut:

Terdapat hubungan yang signifikan antara penggunaan media sosial Instagram berdasarkan intensitas, isi pesan, dan prioritas penggunaannya dengan motivasi wirausaha pebisnis daring komunitas SFS Family dengan hasil yang cenderung kuat yaitu sebesar 48, 3\%. Terdapat hubungan yang signifikan antara penggunaan media sosial Instagram berdasarkan intensitas, isi pesan, dan prioritas penggunaannya dengan peningkatan produktivitas dalam hal ini terkait usaha pebisnis daring. Hal ini disebabkan oleh beberapa faktor yang dibutuhkan oleh responden, yaitu strategi, efektivitas, dan efisiensi dalam menjalankan usaha oleh para pebisnis daring komunitas SFS Family dengan hasil yang cenderung sedang yaitu sebesar $21,8 \%$.

Terdapat hubungan yang signifikan antara motivasi wirausaha pebisnis daring komunitas SFS Family berdasarkan dimensi dorongan, kebutuhan, dan tujuan dengan peningkatan produktivitas. Hal ini disebabkan 
oleh beberapa faktor yang dibutuhkan oleh responden yaitu strategi, efektivitas, dan efisiensi dalam menjalankan usaha oleh para pebisnis daring komunitas SFS Family dengan hasil yang cenderung cukup sedang yaitu sebesar $18 \%$.

Berdasarkan simpulan yang telah dipaparkan sebelumnya, penulis mencoba memberikan beberapa saran yang mungkin dapat menjadi masukan atau kontribusi bagi semua pebisnis daring yang tergabung dalam komunitas SFS Family, dalam hubungannya menggunakan media sosial Instagram dengan motivasi wirausaha untuk meningkatkan produktivitas. Adapun saran-saran yang dapat penulis kemukakan antara lain sebagai berikut: (1) Untuk seluruh pebisnis daring khususnya anggota Komunitas SFS Family agar lebih kompak dalam bekerjasama. Saling membantu setiap anggotanya untuk bertukar informasi seputar bisnis daring, dan menata kembali visi dan misi komunitas agar lebih terstruktur dan terarah, (2) Berkaitan dengan motivasi wirausaha pebisnis daring dan untuk meningkatkan produktivitas yaitu selain menggunakan media sosial Instagram, sebaiknya memiliki situs toko daring tersendiri karena jika hanya di media sosial terkesan "ngontrak" dan tidak berdikari. Manfaat lainnya juga meminimalisir cybercrime seperti adanya hacker, dan (3) Untuk seluruh pebisnis daring yang telah semakin tinggi jam terbangnya di bisnis daring, diharapkan merekrut admin atau pegawai agar tidak lambat respon terhadap konsumen yang akan bertransaksi. Hal ini bertujuan untuk meminimalisir komplain yang sering terjadi dari calon konsumen dan mereka tulis komplain tersebut di komentar pada media sosial Instagram yang tentu saja dapat dibaca oleh semua pengguna.

\section{DAFTAR PUSTAKA}

Ali, M. S., \& Abdurahman, M. (2007). Analisis korelasi, regresi, dan jalur dalam penelitian. Bandung: Pustaka Setia.

Alma, B. (2002). Kewirausahaan. Bandung: Alfabeta.

Ardial, H. (2014). Paradigma dan model penelitian komunikasi. Jakarta: Bumi Aksara.

Ardianto, E., Komala, L., \& Karlinah, S. (2007). Komunikasi massa suatu pengantar. Bandung: Simbiosa Rekatama Media.

Blumer, J. G., \& Katz, E. (1974). The uses of mass communications: current perspectives on gratifications reasearch. London: Sage Publications.

Effendy, O. U. (2003). Ilmu, teori, dan filsafat komunikasi. Bandung: Citra Aditya Bakti.

Jo Kim, A. (2000). Community building on web. Berkeley: Peachpit Press.

Kotler, P. (2000). Manajemen pemasaran. Jakarta: Prenhallindo.

Littlejohn, S. W. \& Foss, K. A. (2009). Encyclopedia of communication theory. California: Sage Publications, Inc.

Mulyana, D. (2007). Ilmu komunikasi suatu pengantar: Bandung: Remaja Rosdakarya.

Nurudin. (2011). Pengantar komunikasi massa. Jakarta: Kencana Persada.

Rachmat, K. (2009). Teknik praktis riset komunikasi. Jakarta: Kencana Prenada Media.

Rakhmat, J. (2009). Metode penelitian komunikasi. Bandung: Remaja Rosdakarya.

Severin, W. J. \& Tankard, J. W. (2001). Teori komunikasi: sejarah, metode, \& terapan di dalam media massa;edisi kelima. Jakarta: Kencana.

Singarimbun, M. \& Effendi, S. (1995). Metode penelitian survei. Jakarta: Pustaka LP3ES Indonesia.

Turner, W. \& Turner, L. H. (2012). Pengantar teori komunikasi: analisis dan aplikasi. Jakarta: Salemba Humanika. 